\title{
Profitability, Marketing Efficiency and Value Addition of Timber Industry in Ife East Local Government of Osun State, Nigeria
}

\section{${ }^{*}$ BABATUNDE, TO; ${ }^{2}$ BABATUNDE, OO; ${ }^{3}$ BABATUNDE, KO; ${ }^{4}$ ADULOJU, AR; 5 OLUWALANA, T; ${ }^{1}$ INYANG, V}

\begin{abstract}
${ }^{* 1}$ Department of Forestry Technology, Federal College of Forestry, Ibadan Oyo State, Nigeria; ${ }^{2}$ Department of Wood and Paper Technology, Federal College of Forestry Ibadan, Oyo State, Nigeria; ${ }^{3}$ Department of Basic Sciences, Federal College of Wildlife Management, New Bussa, Niger State, Nigeria; ${ }^{4}$ Department of Agricultural Technology, Federal College of Forestry Ibadan, Oyo State, Nigeria; ${ }^{5}$ Department of Basics and General Studies, Federal College of Forestry, Ibadan, Oyo, Nigeria
\end{abstract}

*Corresponding Author Email: Sollybee2012@gmail.com; Tel: +2348033948859

\begin{abstract}
The study focused on marketing and value of additions of timber in Ife East Local Government, Osun state Nigeria. Specifically, the study examined the market efficiency, determined the profitability of the timber business, examine the level of value addition and the constraints facing the timber industry. Data were collected with the use of primary and secondary data. Primary data needed for the study were generated from structured questionnaire. Fifteen sawmills were randomly selected and one hundred and fifty questionnaires were distributed to the timber marketer and furniture $\mathrm{m}$ firm. One hundred and forty eight were retrieved. The data collected were analyzed using descriptive and budgetary analyses. The result showed that males had the highest percentage $(89.2 \%)$. Majority of the respondents were within the age range of $40-50$ years $(83.8 \%)$ and most were married $(81.8 \%)$ it was further revealed that $(67.6 \%)$ had regular supply of their product and the means of transportation was lorry (44.6\%). The study also revealed that benches with $42 \%$ added more value addition to the industry. It showed that the year 2013 had the highest efficiency with 2.6. The budgetary analysis showed that the average revenue for the industry for the year 2012-2018 ranged between N2, 285,108.45, 889,107.12. It also revealed that the total profit for the timber ranged between 7, 340, 54.59 and 2,304,897.47.government policy, inadequate facilities in the market, inadequate facilities in the market, inadequate credit facilities, inadequate power supply and high cost of transportation were some of the constraint faced by the timber industry in Ife East Local Government.
\end{abstract}

\section{DOI:https://dx.doi.org/10.4314/jasem.v24i4.7}

Copyright: Copyright $($ C 2020 Babatunde et al. This is an open access article distributed under the Creative Commons Attribution License (CCL), which permits unrestricted use, distribution, and reproduction in any medium, provided the original work is properly cited.

Dates: Received: 16 February 2020; Revised: 21 March 2020; Accepted: 27 March 2020

Keywords; profitability, marketing efficiency, timber, value addition, industry

A forest is a large area dominated by trees. Hundreds of more species definitions of forest are used throughout the world, incorporating factors such as tree density, tree height, land use, legal standing and ecological function (Johnson, 2013) food and agricultural organization definition, forest covered 4billion hectares(9.9) (15 million square miles) or approximately 30 percent of the world's land area in 2006. Timber has been used as a building material for over 400,000 years and it is very common and best known material for house construction including ramming of floors, walls and roofs. According to (cumming ham et al., 2005) timber accounts for about half of worldwide wood consumption Timber marketing is an asset in the economy of timber. According to (Lintu, 2005) marketing provides a means through which people can create efficient economic value for their resources and products. Consequently, efficiency in timber marketing is an economic asset to the forestry sub-sector for a sustained resource production, distribution and consumption. An efficient marketing system of timber will provide a means for maximizing products values and also stimulating equitable distribution of its economic benefits among the different actors in the market. (Agustion and Poopola, 2011). Marketing efficiency is the provision of the best services to producers and consumers consistent with the prices both are willing to accept (Tee, 2007). It is the achievement of the highest return of the resources employed. The efficiency of marketing is therefore a function of what comes out from it structure, conduct and performance. Thus, (Popoola and Rahji, 2001) posited that an efficient marketing system is a prerequisite for increased and sustained production, and so, it is relevant in stimulating and producing forestry development and economic growth. This therefore helps in appraising the extent to which 
interaction between buyers and sellers in the market stimulate outcome that are consistent with profit levels, sales volume, utilization and sustainability (Olukosi, 2005). Furniture is one of the most important home accessories because it adds style and elegance beside their primary functional designs. Wooden furniture are usually present in homes, offices and social infrastructure buildings such as schools, hotels, hospitals, etc. They contribute to the beautification and aesthetics of the place. Furniture are in various forms, such as, doors, tables, chairs, decorations, cabinets and shelves, cupboards, beds, etc. (Ngui et al.,2011) opined that furniture has the highest value-added component among the major wood-based products. This study wish to examine profitability, marketing efficiency and value addition of timber industry in Ifeeast Local government of Osun State Nigeria.

\section{MATERIALS AND METHODS}

Study Area: The study was carried out in Ife East of Osun state, Nigeria. Ife East is a local government area in Osun state, with headquarters in Oke Ogbo in Ile Ife. The local government area is in Osun East senatorial district. Ife East local government area also forms a federal constituency alongside Ife Central, Ife North and Ife South local government areas.

Ife East local government area covers an area of $172 \mathrm{~km} 2$. The local government area is bounded to the north by Ife Central local government area, to the east by Atakumosa west local government area, to the south by Ife South local government area, and to the West by Ife north Local government area.

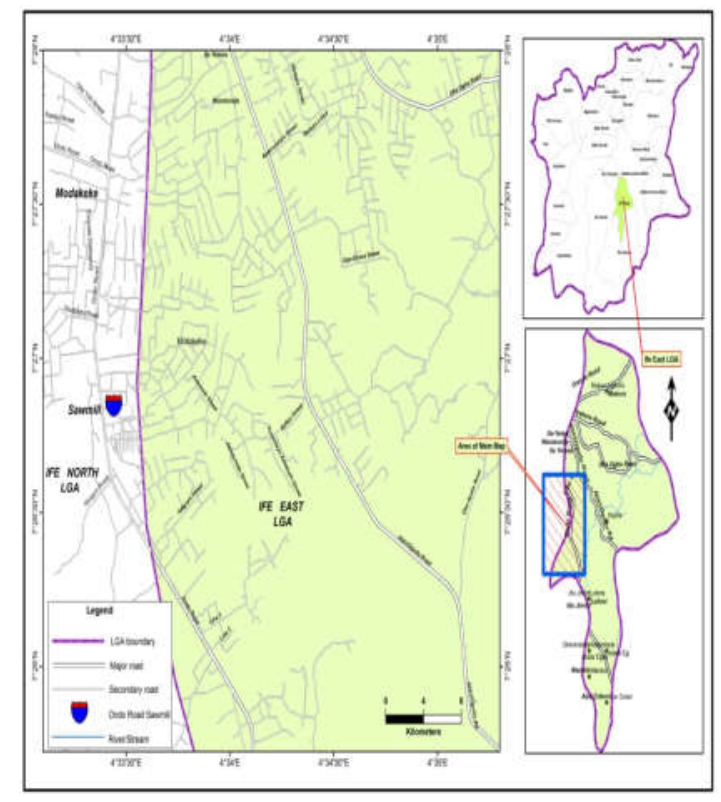

Fig 1. Map Showing the Study Area
Latitudes $7^{\circ} 28^{\prime} \mathrm{N}$ and $7^{\circ} 45^{\prime} \mathrm{N}$ and longitudes $4^{\circ} 30^{\prime} \mathrm{E}$ and $4^{\circ} 34^{\prime} \mathrm{E}$. Ife East is a rural area with settlements where agriculture is occupied by most. Ife has an undulating terrain underlain by metamorphic rocks and characterized by two types of soils, deep clay soils on the upper slopes and sandy soils on the lower parts. Within the tropical savanna climate zone of West Africa, It has average rainfall of 1,000-1,250 mm (3949 in) usually from March to October and a mean relative humidity of $75 \%$ to $100 \%$. Ife is east of the city of Ibadan and connected to it through the IfeIbadan highway; Ife is also $40 \mathrm{~km}(25 \mathrm{ml})$ from Osogbo and has road networks to other cities such as Ede, Ondo and Ilesha. There is the Opa River and reservoir that serves as a water treatment facility for O. A. U

Types and Sources of Data: Primary and secondary data were used in this study. The primary data was collected through the use of structured questionnaire to obtain pertinent information in social economic characteristics involved in timber processing and marketing such as nature of business, ownership of business, business operation capital, number of workers, annual income, income level, expenditures etc. Secondary data was obtained from Osun state ministry of forestry, National Bureau of statistics, internet facilities and published journals and articles.

Sampling technique: Multistage sampling was used in this study. In the first stage, Ife east local government was purposively chosen. The reason being that it has the largest forest coverage area and housed the highest saw-mills and forest reserves in the area. Secondly, fifteen saw-mills were randomly selected from the local government. Thirdly, six (6) timber marketers (sellers) and four (4) furniture (maker) firms were randomly selected from each sawmill. Altogether one hundred and fifty (150) questionnaire were administered but one hundred and forty eight (148) were retrieved.

Method of data analysis: Data was analyzed using descriptive statistics, marketing efficiency was analyze using: Market efficiency index (MEI) as used by (Olokosi and Isitor, 1990); (Ekunwe et al., 2008)

$$
M . E=T R / T M C
$$

Where $\mathrm{TR}=$ total revenue and $\mathrm{TMC}=$ total marketing cost.

Profitability was calculated using budgetary analysis the following profitability were calculated 


$$
\begin{aligned}
& R M C F=T V P-T C \\
& R R T I=100\left(\frac{R M C F}{T C}\right.
\end{aligned}
$$

Profitability Ratios: Rate of Return (ROR) and Rate of Return on investment (RORI) are two alternative profitability used in comparing the level of profitability in the study area.

$$
\begin{gathered}
\% R O R=T R \times 100 / T C \\
R R T I=1 O O(T R-T C) / T C
\end{gathered}
$$

Where; $\mathrm{RMCF}=$ Return to management capital and family labour or net income, TVP $=$ Total value product, $\mathrm{TVC}=$ Total variable cost, $\mathrm{RRTI}=$ Rate of Return on Investment, $\mathrm{TC}=$ Total cost, $\mathrm{ROR}=$ rate of return, $\mathrm{RFC}=$ Return on fixed cost (Gross margin), $\mathrm{RRFC}=$ Rate of return on fixed cost. Value addition in the timber industry in the study area. This was analyzed using value addition.

Value added is define as sale revenue minus all purchases. (Raw material component, supply energy and services from one enterprise to other enterprise). Purchase from another enterprises in the same sawmill was reacted as outside purchases. The value added as a percentage of sales is given thus:

$$
V A=\frac{100(S-P)}{S}
$$

Where: $\mathrm{VA}=$ Value added and $\mathrm{S}=$ Sales

Table 1. Selected Sawmaills in the study Area

\begin{tabular}{llll}
\hline Sawmills & $\begin{array}{l}\text { Timber } \\
\text { Marketers }\end{array}$ & $\begin{array}{l}\text { Furniture } \\
\text { Firms }\end{array}$ & Total \\
\hline Ifesowapo sawmill opa road,Ile ife & 6 & 4 & 10 \\
Orisunmibare sawmill Ondo road, Ile ife & 6 & 4 & 10 \\
Ajowa sawmill Ondo road, Ile ife & 6 & 4 & 10 \\
Atagijere sawmill ondo road, Ile ife & 6 & 4 & 10 \\
Olowoibadan sawmill ondo road, Ile ife & 6 & 4 & 10 \\
Alubarika sawmill ondo road, Ile ife & 6 & 4 & 10 \\
Alalamole sawmill ondo road, Ile ife & 6 & 4 & 10 \\
All is well sawmill Owo eye ondo road, Ile ife & 6 & 4 & 10 \\
Oyebolami sawmill ondo road, Ile ife & 6 & 4 & 10 \\
Ademiju sawmill ondo road, Ile ife & 6 & 4 & 10 \\
Oluwatoyin sawmill ondo road, Ile ife & 6 & 4 & 10 \\
Omo olu sawmill ondo road, Ile ife & 6 & 4 & 10 \\
Omo olu sawmill ondo road, Ile ife & 6 & 4 & 10 \\
Alfa wasiu sawmill ondo road, Ile ife & 6 & 4 & 10 \\
Alahji Taofeek ondo road, Ile ife & 6 & 4 & 10 \\
Arowo sawmill ondo road, Ile ife & 6 & 4 & 10 \\
\hline
\end{tabular}

\section{RESULTS AND DISCUSSIONS}

Table 2 present the result of the socio demographic characteristics of the respondent. The result revealed that $83.8 \%$ are of age $40-50$ while $3 \%$ are of age 50 60 and $21 \%$ are of age $30-40$. The result showed that majority were adult. This result corroborate the findings of (Okumadewa et al.,2000) which stated that those in the age range of 40-50 years of age were productive and have the power to produce work and not in agreement with the result from the market performance of irvingia wombulus (Usman et $a l ., 2015)$ who said that majority were of age 30-40. The result revealed that most of the timber marketers and furniture makers were male (89.2\%), which means majority of the respondent were male and they have more energy to carry out the task. This result is in agreement with (Olawumi and Okunlola, 2015) when they stated that majority of the respondent in Ondo sawmill were male and the result disagree with (Alfred and Akitade, 2002) when they opined that sawn wood marketing were dominated by female. The result further revealed that $81.8 \%$ were married while $21 \%$ were widower $3 \%$ were widow and $3 \%$ were single. Marital status determine the level of household size which by extension may indicate the available labor supply, family, income composition and savings pattern(Mafimimisebi et al.,2000) opined that marital status of a person determines the degree of responsibility of that person in the society and further submit that, marital status distribution is very important as it helps to have an idea of a marketing participant's devotion to the marketing process and the likely outcome of this on his or her business activities. Marriage confers responsibility (Akinbile, 2007). Furthermore $55.4 \%$ of the respondent had secondary education, $33.1 \%$ and $11.5 \%$ have tertiary and primary education respectively. Formal education for most market stake holders confers a wide range of 
opportunities and advantages for success in life compared with illiteracy. Based on a prior, it is expected that higher levels of educational attainment by a markets dynamics and thus better profit from use of sound business principles and wise business decisions. Education enhances the efficiency of trade business (Oluyole and Usman, 2006). This study contradicts earlier study by (Alfred and Akinade, 2002) on wood marketing where majority of the sellers were illiterate.

The table revealed that $2.0 \%$ realized $\$ 1,000,01-\mathbb{N}$ 200,000 per annum, $14.2 \%$ realized N 2000, 0014000,000 per annum and $83.8 \%$ realized above 4000,000 as annual income. This result implies that majority of respondent realized $\$ 4,000,000$ as annual income. The mean annual income for the industry was \# 2,700,000.5. The result agreed with (Babatunde,2018) who found that annual income earned by timber industry in Ijebu North Local Government was well above the Federal Government approved minimum wage.

The result also shows that $0.7 \%$ had access to less than \$ 500,000 to start their business, $1.4 \%$ had access to above $\$ 500,000,16.2 \%$ had access to $\$ 100,001-\mathbb{N}$ 500,000 e.t.c. the mean business operational capital for timber industry was $\$ 3,025,005$. This result is in agreement with (Akanni and Adetayo, 2011) which found out that amount of working capital for a business enterprise often determines the level of output and accruable profit margin.

Table 2: Socio-demographic characteristics of respondent / saw-

\begin{tabular}{lll}
\multicolumn{3}{c}{ millers in the study area } \\
\hline Variables & frequency & percentage \\
\hline Gender & 132 & 89.2 \\
Male & 16 & 10.8 \\
Female & 148 & 100 \\
Total & & \\
\hline Education & 17 & 11.5 \\
Primary & 82 & 55.4 \\
Secondary & 49 & 33.1 \\
Tertiary & - & - \\
No formal & 148 & 100 \\
Total & & \\
\hline Age & 21 & 14.2 \\
30-40 & 124 & 83.8 \\
40-50 & 03 & 2.0 \\
50-60 & - & - \\
60above & 148 & 100 \\
Total & & \\
Marital status & 03 & 2.0 \\
Single & 121 & 81.8 \\
Married & 03 & 2.0 \\
Window & 21 & 14.2 \\
Widower & - & - \\
Divorced & 148 & 100 \\
Total & & \\
Supply of product & & \\
\hline & &
\end{tabular}

\begin{tabular}{|c|c|c|}
\hline Variables & frequency & percentage \\
\hline Regular supply & 100 & 67.6 \\
\hline Not regular & 48 & 32.4 \\
\hline Total & 148 & 100 \\
\hline \multicolumn{3}{|l|}{ Means of transportation } \\
\hline Truck & 67 & 45.3 \\
\hline Lorry & 66 & 44.6 \\
\hline Car & 15 & 10.1 \\
\hline Total & 148 & 100 \\
\hline \multicolumn{3}{|l|}{ Years of establishment } \\
\hline 1-3years & 10 & 6.7 \\
\hline 4-6years & 17 & 11.5 \\
\hline 7-9years & 21 & 14.2 \\
\hline Above10years & 100 & 67.6 \\
\hline Total & 148 & 100 \\
\hline \multicolumn{3}{|l|}{ Main occupation } \\
\hline Saw mailers & 17 & 11.5 \\
\hline Furniture & 49 & 33.1 \\
\hline Timber sellers & 82 & 55.4 \\
\hline Total & 148 & 100 \\
\hline \multicolumn{3}{|l|}{ No of Workers } \\
\hline 1-3workers & 7 & 4.7 \\
\hline 4-5workers & 33 & 22.3 \\
\hline Above6workers & 100 & 73.0 \\
\hline Total & 148 & 100 \\
\hline \multicolumn{3}{|l|}{ Annual income } \\
\hline Less than 500,000 & - & - \\
\hline $1,000001-2,000000$ & 3 & 2.0 \\
\hline $2,000000-4,000000$ & 21 & 14.2 \\
\hline Above 4,000000 & 124 & 83.8 \\
\hline Total & 148 & 100 \\
\hline \multicolumn{3}{|c|}{ Mean annual income } \\
\hline \multicolumn{3}{|c|}{ Nature of business ownership } \\
\hline Private & 148 & 100 \\
\hline Public & - & - \\
\hline Total & 148 & 100 \\
\hline \multicolumn{3}{|c|}{ Ownership of lorry/truck } \\
\hline Yes & 132 & 89.2 \\
\hline No & 16 & 10.8 \\
\hline Total & 148 & 100 \\
\hline \multicolumn{3}{|c|}{ Business operation capital } \\
\hline Less than 500,000 & 1 & 0.7 \\
\hline $500,001-100,0000$ & 121 & 81.8 \\
\hline $100,0000-500,0000$ & 24 & 16.2 \\
\hline Above 500,0000 & 2 & 1.4 \\
\hline Mean business capital & $3,025,00.5$ & \\
\hline Total & 148 & 100 \\
\hline \multicolumn{3}{|l|}{ Nature of business } \\
\hline Retailers & 38 & 25.7 \\
\hline Wholesalers & 11 & 7.4 \\
\hline Both & 99 & 66.9 \\
\hline Total & 148 & 100 \\
\hline \multicolumn{3}{|c|}{ Type of business ownership } \\
\hline Corporation & 30 & 20.3 \\
\hline Co-operative society & 13 & 12.2 \\
\hline Partnership & 20 & 13.5 \\
\hline Sole proprietorship & 80 & 54.0 \\
\hline Total & 148 & 100 \\
\hline
\end{tabular}

The table 2 shows the budgetary analysis of timber industries in Ife east of Osun state. The average revenue for the industry for year 2012-2018 ranged between $¥ 2,285,108.45-\$ 3,889,107.12$. The 
average fixed cost of the industry ranged between $\$ 1$, 257,781.64- $\$ 1,257,781.64$. The average total variable cost ranged between $\$ 287,703.71$ to 326,428.08. The net profit ranged between $\$ 7,340,54.59$ and $\$ 2,304,897.47$. The rate of return on investment were $10.6 \%, 14.5 \%, 0.67 \%, 13.1 \%$, $13.9 \%, 0.47 \%$ and $0.10 \%$. This implying that rate of return on investment was high in the timber industry in Ife east. This result indicates that for every naira invested (also known as return to capital) $10-\mathbb{1} 15$ was realized and the rates of return on fixed cost follow the same trend. On the basis of this, it can be said that sawmill industries were more profitable in Ife east of Osun state. This result agreed (Babatunde et al 2017) who found out that the timber industries in Ijebu ode were profitable.

Table: 3. Budgetary Analysis of timber industry in the study area.

\begin{tabular}{|c|c|c|c|c|c|c|c|}
\hline & 2012 & 2013 & 2014 & 2015 & 2016 & 2017 & 2018 \\
\hline & \multicolumn{7}{|c|}{ Variable Cost } \\
\hline Transportation ( $¥$ ) & $38,898.37$ & $35,972.63$ & $33,557.69$ & $37,480.77$ & $32,932.08$ & $30,480.77$ & $31,989.18$ \\
\hline Labour $(\#)$ & $15,878.32$ & $17,057.72$ & $12,832.69$ & $10,385.00$ & $14,148.55$ & $18,442.31$ & $16,911.64$ \\
\hline $\begin{array}{l}\text { Fuel and power } \\
\text { (A) }\end{array}$ & $36,858.10$ & $45,209.88$ & $33,157.33$ & $39,157.69$ & $40,373.08$ & $48,979.02$ & $35,503.85$ \\
\hline Tax ( & 100 & 1000 & 1000 & 1000 & 1000 & 1000 & 1000 \\
\hline $\begin{array}{l}\text { Processing cost } \\
\text { (A) }\end{array}$ & $133,890.18$ & $167,391.99$ & $140,344.77$ & $144,816.41$ & $132,996.02$ & $129,856.49$ & $150,918.04$ \\
\hline $\begin{array}{l}\text { Membership due } \\
\text { (A) }\end{array}$ & $4,391.89$ & $4,391.89$ & $4,391.89$ & $4,391.89$ & $4,391.89$ & $4,391.89$ & $4,391.89$ \\
\hline $\operatorname{Rent}(\mathbb{N})$ & $22,442,31$ & $22,442,31$ & $22,442,31$ & $22,442,31$ & $22,442,31$ & $22,442,31$ & $22,442,31$ \\
\hline \multirow[t]{2}{*}{ Maintenance ( $(\mathbb{N})$} & $35,344.49$ & $32,961.66$ & $40,803.76$ & $37,449.56$ & $35,966.76$ & $37,679.43$ & $31,405.55$ \\
\hline & \multicolumn{7}{|c|}{ Total Variable Cost $(\AA)$ Fixed Cost Depreciation On; } \\
\hline Band saw ( & $124,5833.33$ & $124,5833.33$ & $124,5833.33$ & $124,5833.33$ & $124,5833.33$ & $124,5833.33$ & $124,5833.33$ \\
\hline Circular saw (\$) & $61,708.33$ & $61,708.33$ & $61,708.33$ & $61,708.33$ & $61,708.33$ & $61,708.33$ & $61,708.33$ \\
\hline $\begin{array}{l}\text { Planning machine } \\
\text { (A) }\end{array}$ & $94,7961.66$ & $94,7961.66$ & $94,7961.66$ & $94,7961.66$ & $94,7961.66$ & $94,7961.66$ & $94,7961.66$ \\
\hline Buildings (\#) & $86,616.66$ & $86,616.66$ & $86,616.66$ & $86,616.66$ & $86,616.66$ & $86,616.66$ & $86,616.66$ \\
\hline \multirow[t]{2}{*}{ Generating set ( } & $36,911.66$ & $36,911.66$ & $36,911.66$ & $36,911.66$ & $36,911.66$ & $36,911.66$ & $36,911.66$ \\
\hline & \multicolumn{7}{|c|}{ Total Fixed Cost $(\mathbb{N})$} \\
\hline Total cost $(\#)$ & $1,542,093.46$ & $1,584,209.72$ & $1,546,312.08$ & $1,554,905.27$ & $1,542,905.27$ & $1,542,062.33$ & $1,551,053.86$ \\
\hline Total revenue ( & $3,189,979.96$ & $3,889,107.19$ & $2,584,206.33$ & $3,595,401.05$ & $3,689,462.65$ & $2,285,108.45$ & $3,225,678.21$ \\
\hline $\begin{array}{l}\text { Profitability } \\
\text { indicator on } \\
\text { investment }\end{array}$ & 1.06 & 1.45 & 0.67 & 1.31 & 1.39 & 0.47 & 0.10 \\
\hline $\begin{array}{l}\text { Rate of return on } \\
\text { fixed cost }\end{array}$ & 2.37 & 2.83 & 1.83 & 2.62 & 2.70 & 1.58 & 2.33 \\
\hline
\end{tabular}

Source: Field survey 2019

Table: 4 Market efficiency of timber industries in Ife east

\begin{tabular}{|c|c|c|c|c|c|c|c|}
\hline & 2012 & 2013 & 2014 & 2015 & 2016 & 2017 & 2018 \\
\hline Total cost & $1,542,093.46$ & $1,546,209.08$ & $1,546,312.08$ & $1,554,905.27$ & $1,542,062.33$ & $1,551,053.86$ & $1,552,344.1$ \\
\hline Total revenue $\mathrm{N}$ & $3,189,979.96$ & $3,889,107.19$ & $2,58,206.33$ & $3,595,401.05$ & $3,689,462.63$ & $2,285,462.65$ & $3,225,678.21$ \\
\hline Efficiency & 2.1 & 2.6 & 1.7 & 2.4 & 2.4 & 1.5 & 2.1 \\
\hline
\end{tabular}

Source: Field survey 2019

Table 5.Value added sales ratio for the timber industry

\begin{tabular}{llll}
\hline Product & Average purchase & Average sales & Value added/sales ratio \\
\hline Set of chair & 119833.33 & 164666.66 & 0.27 \\
Office chair & 36083.33 & 56166.66 & 0.35 \\
Doors & 8400 & 12533.33 & 0.32 \\
Bookshelf & 11883.33 & 18016.66 & 0.34 \\
Pulpit & 10950 & 16000 & 0.31 \\
Prayer desk & 11250 & 16883.33 & 0.33 \\
Wardrobe & 37383.33 & 52583.33 & 0.28 \\
Pupils chair & 4533.33 & 7366.66 & 0.38 \\
Kitchen cabinet & 17850 & 29216.66 & 0.38 \\
Lectern & 8133.33 & 13758.33 & 0.40 \\
Office Tables & 7480 & 11983.33 & 0.37 \\
Benches & 1181.66 & 2041.66 & 0.42 \\
\hline
\end{tabular}

The table above shows the market efficiency of the business from year $2012-2018$ was $2.1,2.6,1.7,2.4$, $2.4,1.5$ and 2.1 respectively. The result implies that the market was efficient. The year with the high efficiency was 2013 with the value 2.6. This result is in line with (Sambe et al, 2015) who stated that sawmill market in Benue is efficient with high financial returns on the investment by the marketers. 
According to (Kydd, 1992) and (Ozogwu, 2002), the value of marketing efficiency ranges from $0 \%$ to infinity. If marketing efficiency is $100 \%$ (unity), it shows that the market is efficient, whereas if marketing efficiency is greater than $100 \%$ then there is excess profit. Also if marketing efficiency is less than $100 \%$ there is inefficiency.

Table 5 shows the value added sale ratio for timber industry; since furniture industry added value to timber industry and output of sawmill input in furniture industry. From the table value added sales ratio of $27 \%$ for set of chair, $35 \%$ for office chair, $32 \%$ for doors, $34 \%$ for bookshelf's, $31 \%$ for pulpit, $33 \%$ for prayer desk, $28 \%$ for wardrobe, $38 \%$ puplis chair, $38 \%$ for kitchen cabinet, $40 \%$ for lectern, $37 \%$ for office tables and $42 \%$ for benches. This result implies that all the produce added value to the timber industries but benches with $42 \%$ added more value sales ratio to the timber industry in Ife east.

Table 5. Constraints Facing the Timber Business

\begin{tabular}{lll}
\hline Constraint & Frequency & Percentage \\
\hline Government policy & 29 & 19.6 \\
Inadequate facilities in market & 24 & 16.2 \\
Inadequate credit facilities & 24 & 16.2 \\
Inadequate power supply & 48 & 27.0 \\
High cost of transportation & 31 & 20 \\
\hline
\end{tabular}
Source: field survey, 2019

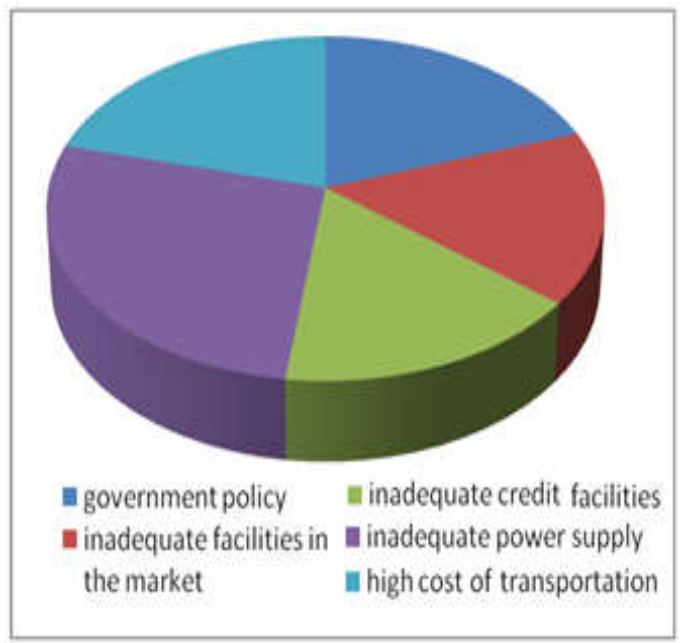

Fig 2.Constraints

The table 6 shows that timber industries in the study area encountered several constraints. $27.0 \%$ are faced with inadequate power supply, $20.9 \%$ incurred high cost of transportation, $19.6 \%$ complained of unfavorable government policy and $16.2 \%$ with inadequate facilities in the market and credit facilities. The timber industries faced with high cost of energy and power supply due to epileptic power supply and the demand for diesel and petrol to power their machine is high. And also high cost of transportation due to the bad roads where they sourced their timber and available transport tend to exploit the respondent by charging exorbitant fee. These results corroborate the prospect of (Akanni and Adetayo, 2011) who observed that high cost of energy affected sawmilling timber industries in Ijebu Ode.

Conclusion: In the context of the result obtained from this study, timber business is an important source of income to many households in Nigeria and the study area in particular, it is however experiencing major setbacks. The identified constraints to the development of timber industry need to be addressed if the industry must move forward. For instance problem of inadequate credit facilities may be addressed by coming together of the timber business men and women to form cooperative societies so that they can have access to sufficient credit facilities that could mobilized for their business operations. Based on the findings and conclusions drawn from this study, the following recommendations were made, to improve the supply level of timber business in Ife East there is need to improve on the supply of energy and power for production processes in the study area. Government should encourage on private tree plantation so as to make available more trees since the demand for timber is at increase.

\section{REFERENCES}

Agbonlahor MU (2010): productivity dispersion and resources of Technical in efficiency Smallholder timber mills in Ogun state Nigeria. J. Humanities, Soc. Sci. Creative Arts. 5. 49-60.

Agustion, S; Popoola (2011): Non-wood forest products and services for socio-Economic development. A compendium for technical and professional forestry education. The African Forest Forum, Nairobi, Kenya.2011; 219.6.Assessment of status and trends in forest industries of Ghana, Nigeria and Cameroon. Final Report to the African Forestry Research Network (AFORNE, Kenya) 150Pp.

Akanni. KA; Adetayo AO (2011): Estimation of cost return structure and technical efficiency in sawmilling industry in ijebu division Ogun state, Nigeria. J. Fores. Res. Manage.8: 64-79

Akinbile, CO, OA Fakayode and KO Sanusi (2011). Using Bamboo (Bambusa vulgaris) as field drainage material in Nigeria. Afr. J. Environ. Sci. Technol. 5(12): 1124-1127 
Azeke I (2003): Forests, people and the Environment. Proceedings of a National Workshop organized by FANCONSULT and Edo State Chapter of Forestry Association of Nigeria held in Benin City, Edo State. 5 - 6 September, 2002. pp. 27-40

Babatunde TO, Babatunde OO, Adekola PJ, Ojo MO, Adeniji RT and Shitu AJ (2013). Marketing of some selected non timber forest products in Boluwaduro local government area of Osun state. Journal of Qualitative Education 9(2) 167-176.

Babatunde TO; Usman, JM (2013). Structure, conduct and performance of timber marketing in Ebute Metta Area of Lagos State.

Babatunde TO Babatunde OO Adejumo, AA; Okeleke SO (2017): cost and return structure in sawmill industry in ijebu-ode, Ogun State. J. Res. Forest. Wildlife Environ. 9(3)

Cunning ham, PW, Cunningham MA and Saigo B (2005). Environmental science: A Global concern. $8^{\text {th }}$ edition, m.c Graw Hill600p.

Johnson, S (2013) "Secondary processed wood products." In Tropical forest up-date. 7 (4) 3 - 4

Kehinde, AL; Awoyemi, TT (2009): Analysis of Economic Efficiency in Sawn wood Production in Southwest Nigeria. J. Hum Ecol. 26(3):175-183

Kuje (2010). Determination of technical efficiency and production function for small scale furniture industry in Lafia Metropolis, Nasarawa State Nigeriall J. Aric Soc. Sci.6:64 -66.

Lintu. L (2005). Marketing of non-wood forest products in developing countries. Trade and Marketing of Forest Products. Unasylva. 183(46):4-12.5

Ogunwusi, AA (2011): Strategies for establishment of industrial furniture clusters in Nigeria.\| in L. Popoola, K, Ogunsanwo and F Idumah (Ed). Proceedings of the 34th Annual Conference of the Forestry Association of Nigeria, Osogbo, Osun State 05-10 December, 2011.pp 119-129.
Ogunwusi, A. (2012): The Forest Products Industry in Nigeria. African Research Review 6(4):191-205

Okumadewa. FY, Mafimisebi, JE; Adebayo, S.K. (2000). Profitability of Wholesale and retail sundried meat trade in Ibadan metropolis. J. Technol. Educate. Nig. 5(1). 5-11.

Olawumi, AC; Okunola, G (2015): Development of the Nigerian Particle Board Industry. Ph.D. Thesis Department of Forest Resources Management. University of Ibadan. 317pp

Olukosi A. (2005): Timber certification and the pursuit of credible claim, Unasylva.46. 25-26

Olukosi, JO; Isitor, SU; Ode MO (2005). Introduction to Agricultural Marketing and pies: Principles and Applications. $3^{\text {rd }}$ Edition. Living Books Series. GU. Publications, Abuja Nigeria, pp.20-47

Orimoogunje, S (2013): For Over 15 years, prices of our products have remained unchanged.|lTheSunNewsonlinehttp://www.punc hontheweb.com/article2print.aspx?theatric $=\operatorname{art} 20$ 085050680 Retrieved October 72011.

Popoola LM Rahji and PO Adesoye (2001): Analyses of spatial and Temporal Variations in prices of some sawn wood in south western Nigeria. Ghana J. Forestry. 10: 35-41.

Sambe LN, Tee NT and Dagba BI (2016). Profitability Analysis of Timber Trade: "Potentials for Growth and Development of the Nigeria Sawmilling Industry." Nig. J. For. 23 (1): 85-90

Tee, TN (2010). Practical Issues in Forest Products Marketing (Pp. 132- 152) In: Ijeomah, HM and Aiyeloja (eds.) .2010.Practical Issues in Forest and Wildlife Resources Management. Green Canopy Consultants, Port Harcourt, Rivers State.

Tee, NT (2016): Wood: A versatile material for natural development. Inaugural lecture 